\title{
Inner Ear Gene Therapy in Mouse Models of Genetic Hearing Loss
}

\author{
Jin Woong Choi ${ }^{\mathrm{D}}$ \\ Department of Otorhinolaryngology-Head and Neck Surgery, College of Medicine, Chungnam National University, Daejeon, Korea
}

\author{
유전성 난청 마우스 모델에서의 내이 유전자 치료
}

최진웅

충남대학교 의과대학 이비인후-두경부외과학교실

Received September 9, 2020 Accepted December 10, 2020 Address for correspondence Jin Woong Choi, MD, PhD Department of OtorhinolaryngologyHead and Neck Surgery,

College of Medicine, Chungnam National University, 282 Munhwa-ro, Jung-gu, Daejeon 35015, Korea Tel $+82-42-280-8375$

Fax +82-42-253-4059

E-mail choijw@cnu.ac.kr
Hearing loss is the most frequent sensory disorder affecting newborns and children. About 1 newborn in every 500 suffer from congenital hearing loss, with approximately half of these having a genetic cause. In the last few decades, the study of genetic hearing loss and related mouse models has unveiled molecular, cellular, and physiological mechanisms of the disease. In addition, effective and safe viral vectors for gene delivery to the inner ear have been generated. A growing number of approaches, including gene replacement, gene silencing, and gene editing, have proved effective in mouse models. This article briefly introduces basic strategies of gene therapy, viral vectors used and surgical methods for gene delivery, and reviews the current works on mouse modes of genetic hearing loss.

Korean J Otorhinolaryngol-Head Neck Surg 2021;64(4):215-22

Key Words Animal model - Correction of hearing impairment - Gene therapy ·

Genetic vectors · Nonsyndromic sensorineural hearing loss ·

Sensorineural hearing loss.

\section{서 론}

난청은 가장 흔한 감각기관 질환이다.) 최근 세계보건기구 보고에 따르면 약 4 억 6 천만 명 이상이 난청으로 고통받고 있 고 이 중 3 천 4 백만 명 정도가 소아들이다. ${ }^{2)}$ 선천성 난청은 소 아 난청의 가장 흔한 원인으로 신생아 500 명당 1 명에서 발생 한다. 이 중 약 절반이 유전자 이상에 의해 발생하는 유전성 난청이다. ${ }^{3)}$ 현재까지 150 개 이상의 유전자가 난청과 관련이 있다고 알려졌다. ${ }^{4)}$ 난청의 정도를 고려하여 보청기와 인공와 우(cochlear implant) 등으로 유전성 난청 환자를 치료하고 있다. 그러나 이 방법들은 유전성 난청의 원인 자체를 치료하 는 것이 아닌 청각 재활 방법이다. 유전성 난청을 치료하기 위

This is an Open Access article distributed under the terms of the Creative Commons Attribution Non-Commercial License (https://creativecommons.org/licenses/by-nc/4.0) which permits unrestricted non-commercial use, distribution, and reproduction in any medium, provided the original work is properly cited.
해서는 질환을 일으키는 유전자에 대한 근본적인 접근이 필 요하다. 지난 수십 년간 다양한 마우스 모델(mouse model) 을 통해 유전성 난청의 분자생물학적 기전이 밝혀졌다. 또한 내이(inner ear)로 안전하고 효율적으로 유전자를 전달할 수 있는 다양한 바이러스 벡터(viral vector)들에 대한 활발한 연구가 진행되어 왔다. 따라서 본 종설에서는 이러한 유전성 난청 마우스 모델에서 내이 유전자 치료에 대해 고찰해 보고 자 한다.

\section{유전자 치료 전략}

유전성 난청을 위해 유전자 대체(gene replacement), 유전 자 침묵(gene silencing) 및 유전자 편집(gene editing) 등의 방법들이 주로 사용되고 있다. 유전자 대체는 유전자 치료 방법 중에 가장 흔하게 사용되는 방법으로 변이된 유전자 
complementary deoxyribonucleic acid(cDNA) 대신에 정상 인 야생형(wild-type) cDNA를 전달하는 방법이다. 이 방법 은 유전자 변이로 인해 정상 유전자 산물이 생성되지 않는 변 이(loss of function mutation)에 적합한 방법이다.

유전자 침묵은 antisense oligonucleotide나 ribonucleic acid(RNA) interferase 등의 물질을 이용하여 변이된 유전자 의 번역(translation)이나 전사(translation)를 막는 방법이 다. ${ }^{5,6)}$ 유전자 변이를 통해 생성된 단백질이 이상 기능을 하거 나(gain of function mutation) 정상 기능을 억제하는 역할을 하는 변이(dominant negative mutation)에 적합한 방법이다.

유전자 편집은 clustered, regularly interspaced, short palindromic repeat(CRISPR)/CRISPR-associated nuclease 9, transcriptional activator-like effector nucleases나 zinc finger nucleases와 같은 물질들을 이용하여 변이된 유전자 부분을 잘라내어 편집하는 방법이다. 이론적으로 가장 완벽 한 유전자 치료 방법이기는 하나 내이뿐만 아니라 다른 신체 기관에도 영향을 미칠 수 있고(off-target effect) 편집을 원 하는 부위 주변으로 예기치 않는 다른 변이나 재배열을 발생 시킬 수 있다. ${ }^{7)}$

\section{유전자 전달을 위한 바이러스 매개체}

유전자 치료가 성공적으로 이루어지기 위해 가장 먼저 선 택해야 할 것은 목표 세포로 유전 물질을 전달하기 위한 적 절한 매개체이다. 전달하고자 하는 유전 물질의 크기, 목표 기관 및 전신에 미치는 영향 등에 따라 다양한 바이러스들이 사용되어 왔다. 유전성 난청 연구에서는 아데노바이러스 $(\mathrm{ad}-$ enovirus), 렌티바이러스(lentivirus) 및 아데노연관바이러스 (adeno-associated virus)가 많이 사용되고 있다(Table 1).

아데노바이러스는 adenoviridae군의 바이러스로 2형과 5형 이 가장 많이 사용되고 있다. 높은 효율로 다양한 신체 조직 이나 세포를 감염(transfection)시킬 수 있다. 또한 $36 \mathrm{~kb}$ 정도
의 큰 유전자를 운반할 수 있다. ${ }^{8)}$ 그러나 사람에게 주입되는 경우 질병을 야기할 수 있으며, 내이로 주입되는 경우 청력 손실이 발생할 수 있다.9) 또 다른 단점으로는 숙주의 유전체 (genome)에 결합하지 못하기 때문에 상대적으로 짧게 유전 자가 발현된다. ${ }^{10)}$ 내이에서는 유모세포(hair cell)보다는 지지 세포(supporting cell)에 더 친화적이다. 반면, 전정기관의 경 우에는 유모세포 및 지지세포 모두에 감염을 잘 일으킨다.11,12) 따라서 유전성 난청보다는 이독성 예방이나 재생 연구분야에 좀 더 적합할 수 있다.

렌티바이러스는 retroviridae군에 속하며 사람 면역 결핍 바이러스로부터 주로 기원했다. $8 \mathrm{~kb}$ 정도 크기의 유전자까지 운반할 수 있는 RNA 바이러스로 숙주의 DNA유전체에 통 합될 수 있다. 면역유발반응(immunogenicity)이 비교적 적고 다양한 세포를 감염시킬 수 있다. 또한 청력을 떨어뜨리지 않 기 때문에 내이 유전자 치료에 사용할 수 있는 바이러스 중에 하나이다. ${ }^{13,14)}$ 그러나 아데노바이러스와 유사하게 내이 유모 세포보다는 지지세포나 나선신경절(spiral ganglion)을 잘 감 염시킨다. ${ }^{15,16)}$

아데노연관바이러스는 parvociridae군에 속하는 바이러스 로 $25 \mathrm{~nm}$ 크기의 정이십면체의 캡시드(capsid) 안에 약 $4.7 \mathrm{~kb}$ 크기의 단일 가닥의 DNA로 구성되어 있다. ${ }^{17)}$ 아데노바이러 스나 단순헤르페스바이러스(herpes simplex virus)의 도움없 이 자기 복제가 불가능하다. ${ }^{18)}$ 독성 및 면역유발반응이 매우 낮고, 쉽게 재조합이 가능하기 때문에 현재 유전자 치료 연구 에 가장 많이 사용되는 바이러스 매개체이다. 또한, 다양한 세포에 친화성(tropism)을 보이며 바이러스 자체의 유전체를 제거하고 관심 유전자를 삽입한 재조합 아데노연관바이러스 의 경우 숙주 DNA에 통합되지 않는 장점이 있다. ${ }^{19}$ 재조합 시 야생형에 존재했던 Rep 유전자와 Cap 유전자가 제거되고 관 심 유전자가 역위말단반복(inverted terminal repeat, ITR) 사 이로 삽입된다(Fig. 1). ${ }^{20,21)}$ 현재까지 12가지 이상의 혈청형이 존재하고 100 가지 이상의 변이들이 여러 동물들에서 발견되

Table 1. Comparison of commonly used viruses for inner ear gene therapy

\begin{tabular}{llll}
\hline \multicolumn{1}{c}{ Virus } & \multicolumn{1}{c}{ Characteristic } & \multicolumn{1}{c}{ Advantage } & \multicolumn{1}{c}{ Disadvantage } \\
\hline Adenovirus & A double-stranded DNA virus & Ability to accept reasonably & Transient gene expression \\
& Ability to transduce nondividing cells & large insert (36 kb) & Immunogenicity \\
& No integration into the host cell's DNA & & Viral genome dilution \\
Lentivirus & A complex RNA retrovirus & Ability to accept reasonably & Safety or toxicity issue \\
& Ability to transduce nondividing cells & large insert (8 kb) & \\
& Integration stably into the genome & No viral genome dilution & Small cargo capacity (4.5 kb) \\
Adeno-associated & A single-stranded DNA virus & Minimal immunogenicity & \\
virus & Ability to transduce nondividing cells & & \\
& *No integration into the host cell's DNA & &
\end{tabular}

*recombinant adeno-associated virus. DNA: deoxyribonucleic acid, RNA: ribonucleic acid 
었다. 각 혈청형별로 세포 친화성이 조금씩 다르다. 2형, 4형, 및 8형의 경우에는 나선인대(spiral ligament), 나선연(spiral limbus) 및 나선신경절 같은 조직에 감염을 잘 일으키는 반면, 1 형과 같은 경우에는 유모세포나 지지세포에 감염을 잘 일으 킨다. ${ }^{22)}$ 바이러스가 숙주에 결합할 때 숙주 세포 표면에 있는 세포 수용체와 바이러스 캡시드 사이의 결합 정도에 따라 세 포 친화성이 결정된다. 보편적으로 2형의 ITR 부분과 여러 혈 청형들의 캡시드 부분을 조합한다. 예를 들어 혈청형 8형의 캡시드 부분을 이용하여 재조합하면 ITR은 혈청형 2형이므 로 아데노연관바이러스 $2 / 8$ 로 표현한다. 바이러스에 삽입된 유전자가 발현되기 위해서는 촉진인자(promoter)가 필요한데 아직까지 내이세포에 특정한 촉진인자는 알려져 있지 않아 cytomegalovirus(CMV), chicken beta actin(CBA) 또는 이 두가지를 합성한 $\mathrm{CMV}$-actin-globin 같은 일반적인 촉진인 자 등을 주로 사용한다. ${ }^{23,24)}$ 이 바이러스의 가장 큰 단점은 바 이러스 매개체 중에 유전자 운반량이 가장 작다는 것이다. 운 반량이 $4.7 \mathrm{~kb}$ 에 불과하여 치료 유전자의 코딩 영역이 이 크 기보다 큰 경우 하나의 벡터만으로는 목표 세포에 유전자를 전달할 수 없다. 치료 유전자를 바이러스 운반 한도 내로 두 개로 나누어서 삽입하는 방법으로 이러한 제한을 극복할 수 있다. ${ }^{25,26)}$
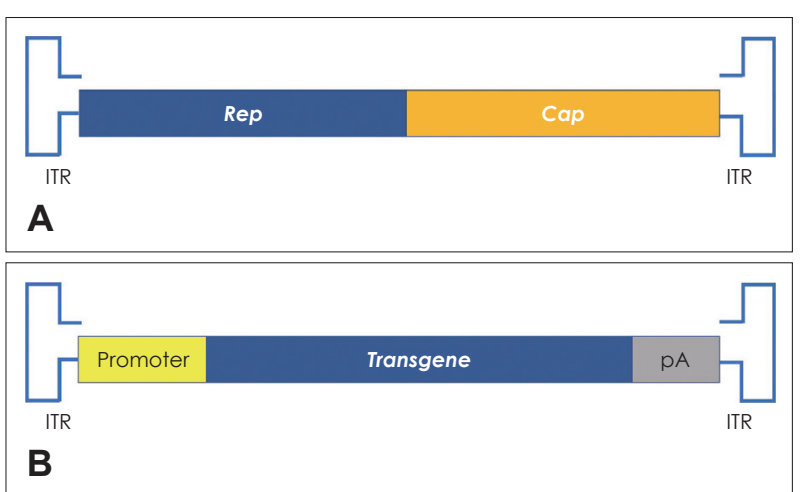

Fig. 1. Structure of AAV. Wild-type (A) and recombinant adenoassociated virus (B). The wild-type AAV genome can be modified by replacing the viral rep and structural cap genes with exogenous transgene. Rep: replication, Cap: capsid, ITR: inverted terminal repeat, pA: poly A tail, AAV: adeno-associated viral vector.

\section{유전자 전달을 위한 수술적 접근법}

적절한 바이러스 매개체를 선택하였다면 치료 유전자를 내 이로 전달하는 과정이 필요하다. 현재까지 동물연구에서는 와 우개방술(cochleostomy), 정원창 주입법(round window injection) 및 반고리관개방술(canalostomy) 등의 세가지 방법 들이 주로 사용되고 있다(Table 2).

와우개방술은 마우스 모델에서는 와우 측벽 혈관조(stria vascularis) 부위를 통해 와우 중간계(scala media)로 바이러 스 벡터를 주입하는 방법으로, 감각상피(sensory epithelium) 가 있는 내림프 공간(endolymphatic space)으로 치료 유전 자를 직접 전달할 수 있다. 그러나 와우에 상당량의 뼈천공 (bone drilling)이 필요하기 때문에 천공 부위 근처의 외유모 세포들이 손상될 수 있다. 이러한 유모세포의 손상으로 청력 이 떨어질 수 있다. ${ }^{11,27)}$

정원창 주입법은 정원창을 통해 유전자를 전달하는 방법 으로 뼈천공이 필요하지 않기 때문에 와우개방술보다 덜 침 습적이다. 그러나 시술 후의 중이강(middle ear cavity) 내의 삼출액이 청력에 영향을 끼칠 수 있고 ${ }^{28)}$ 와우 첨부는 정원창 과 거리가 멀어 감염 효율이 떨어질 수 있다. ${ }^{29}$ 이와 반대로 반 고리관개방술은 표면에 위치한 반고리관을 이용하기 때문에 유양돌기나 중이강을 노출할 필요가 없고 비교적 시술이 간 단하다. ${ }^{30}$ 따라서 직접적인 외유모세포의 손상이나 삼출액 등 의 부작용을 피할 수 있다. 또한 서로 다른 반고리관을 통한 바이러스 벡터의 중복 주입이 가능하다. ${ }^{31)}$

\section{대표적인 유전자 치료 동물연구}

현재까지 많은 유전자가 난청과 관련이 보고되고 있지만 많 게는 60\% 정도의 유전성 난청이 GJB2, SLC26A4 및 TMC1 같은 유전자들의 변이에 의해 발생한다. ${ }^{32-34)}$ 따라서 이러한 변이들에 대해 성공적인 치료가 이루어진다면 많은 환자들에 게 이득이 될 수 있다. 이러한 유전자들과 더불어 청력의 각 단계에 관여하는 중요 유전자들에 대해 동물연구들이 활발 히 진행되어 왔다(Table 3).

Table 2. Comparison of commonly used surgical methods for gene delivery to the inner ear

\begin{tabular}{lcll}
\hline \multicolumn{1}{c}{ Method } & \multicolumn{1}{c}{ Entry site } & Advantage & Disadvantage \\
\hline Cochleostomy & Scala media & Direct access to the sensory & Risk of hair cell and hearing loss \\
Round window injection & Scala tympani & Bone drilling, especially in adult mice \\
& (perilymphatic space) & Lower apex transfection & Middle ear effusion \\
Canalostomy & efficiency than base & \\
& Scala vestibuli & Relatively simple procedure & Bone drilling, especially in adult mice \\
& (perilymphatic space) & Multiple injection using other & \\
& semicircular canals & \\
& &
\end{tabular}


Table 3. Representative studies on inner ear gene therapy in mouse model

\begin{tabular}{|c|c|c|c|c|}
\hline Hearing mechanism & Gene & Animal model & Outcomes & Author (year) \\
\hline \multirow{5}{*}{$\begin{array}{l}\text { Hair cell } \\
\text { morphogenesis } \\
\text { and function }\end{array}$} & Whrn & Whrn wi/wi & Restoration of expression of whirlin & Isgrig, et al. ${ }^{38)}(2017)$ \\
\hline & & & Improvement of hair cell stereocilia length & \\
\hline & Tmcl & Tmcl KO & $\begin{array}{l}\text { Improvement of mechanoelectrical transduction } \\
\text { channel current }\end{array}$ & Askew, et al. ${ }^{22)}(2015)$ \\
\hline & Clrn 1 & $\begin{array}{l}\text { Clrnl KO, cKO, } \\
\text { Clrnl exex4-/- }\end{array}$ & $\begin{array}{l}\text { Preserved hair bundle morphology } \\
\text { Improvement of hearing }\end{array}$ & $\begin{array}{l}\text { Dulon, et al. }{ }^{42)}(2018), \\
\text { György, et al, }{ }^{44)}(2018)\end{array}$ \\
\hline & Ushlc & Ush1c c216G>A & $\begin{array}{l}\text { Improvement of hearing and vestibular function, } \\
\text { normal hair bundle morphology }\end{array}$ & Pan, et al. ${ }^{46)}(2017)$ \\
\hline \multirow[t]{2}{*}{$\begin{array}{l}\text { Synaptic } \\
\text { transmission }\end{array}$} & Vglut3 & Vglut3 KO & $\begin{array}{l}\text { Improvement of hearing, earlier delivery increases } \\
\text { hearing restoration longevity }\end{array}$ & Akil, et al. ${ }^{48)}(2012)$ \\
\hline & Otof & Otof KO & Improvement of hearing & $\begin{array}{l}\text { Akil, et al. }{ }^{25)}(2019) \\
\text { Al-Moyed et al. } \\
\text { (6) }(2019)\end{array}$ \\
\hline \multirow[t]{3}{*}{ Ion homeostasis } & Gjb2 & Gjb2 KO & $\begin{array}{l}\text { Improvement of gap junction function, no hearing } \\
\text { improvement }\end{array}$ & Yu, et al. ${ }^{50)}(2014)$ \\
\hline & Gjb6 & Gjb6 KD & $\begin{array}{l}\text { Improvement of gap junction function, no hearing } \\
\text { improvement }\end{array}$ & Miwa, et al. ${ }^{51)}(2013)$ \\
\hline & SIc26a4 & Slc26a4 KO, KI & Improvement of hearing & Kim, et al. ${ }^{54)}(2019)$ \\
\hline
\end{tabular}

KO: knock-out, cKO: conditional knock-out, KD: knock-down, Kl: knock-in, ex: exon

유모세포의 형성 및 기능: Whrn, Tmc1, Crln1, Ush1c

Whirlin은 유모세포의 섬모(stereocilium)의 길이 형성에 중요한 역할을 하는 골격 단백질이다. Whirlin을 코딩하는 Whrn 유전자에 변이는 상염색체 열성 비증후군 난청 31형과 Usher 증후군 2D형을 일으킨다. ${ }^{35,36)}$ Whirlin 단백질이 결핍 되는 경우에는 와우 및 전정기관의 짧은 섬모로 인해 유모세 포가 제 기능을 하지 못하고 난청과 전정기능 이상이 발생한 다. Whrn 자발 변이 마우스 $\left(W_{h r n}{ }^{\text {wi/wi }}\right)$ 에서 아데노연관바이 러스 2/8-Whrn를 정원창을 통해 내이로 주입한 경우에 섬모 의 길이가 길어지고 전체적인 섬모 다발(stereocilia bundle)의 모양이 정상화되었다. ${ }^{37)}$ 이 연구의 저자들은 후반고리관(posterior semicircular canal)을 통한 반고리관개방술을 이용하 여 추가 연구를 시행하였는데, 정원창을 통한 방법보다 유모 세포로의 감염 효율이 향상되었고 섬모의 길이 변화 뿐만 아 니라 정원창으로 주입했을 경우 관찰되지 않았던 청력 및 전 정기능의 회복도 관찰하였다. ${ }^{38)}$ 내유모세포(inner hair cell)의 감염률은 정원창 접근법을 시행했던 경우에는 10 15\%, 반고 리관개방술을 시행했던 경우에는 평균 71 81\%였다. 이처럼 같은 마우스 모델과 같은 바이러스 벡터를 이용하였는데도 불구하고 주입하는 경로에 따라 다른 결과를 보일 수 있기 때 문에 적절한 수술 방법을 선택하는 것이 필요하다.

Tmc1 유전자는 유모세포의 말단에 위치하는 mechanoelectrical transduction channel(MET 통로)의 일부인 Tmc1 단백질을 코딩한다. Tmc1 변이가 있는 경우 MET 통로 이상 및 유모세포의 퇴화로 난청이 발생한다. ${ }^{39,40)}$ 상염색체 열성 비 증후군 난청 7형 및 11형이 이러한 Tmc1 변이에 의해 발생한
다. Tmc1 knock-out 마우스에서 아데노연관바이러스 2/1CBA-Tmc1을 생후 0 2일의 시기에 주입한 연구에서 바이러 스 벡터 주입 후 야생형과 유사한 정도의 MET 통로 기능의 회복을 관찰할 수 있었다. 그러나 대부분의 바이러스 벡터 감 염은 내유모세포에 국한되어 청력의 회복은 관찰할 수 없었 다.22) 이 연구의 저자들은 외유모세포에도 감염 효율이 좋은 아데노연관바이러스 2/Anc80L65 합성 바이러스를 이용해서 후속 연구를 진행하였는데 내유모세포 뿐만 아니라 외유모 세포에도 높은 감염 효율을 보여 성공적인 청력 회복을 관찰 할 수 있었다. ${ }^{41)}$ 이처럼 전달 매개체인 바이러스 벡터의 선택 에 따라 유전자 치료결과가 달라질 수 있다.

Crln1 유전자는 섬모 다발의 형성에 관여하는 clarin-1 단 백질을 코딩한다. ${ }^{42,43)} \mathrm{Crln} 1$ 변이는 Usher 증후군 3형의 원인 으로 $\operatorname{Crln} 1$ knock-out 마우스는 시간이 지남에 따라 점차적 으로 유모세포의 섬모 다발이 퇴화되며 MET 통로가 손상되 어 진행형 난청이 발생한다. ${ }^{44}$ 세가지 종류의 마우스 모델에서 서로 다른 종류의 아데노연관바이러스를 이용한 유전자 치료 연구가 시행되었다. 출생 후 Crln1이 하향 조절(down regulation) 되도록 만든 마우스에 아데노연관바이러스 2-CBAclrn1을 주입한 경우에는 평균 $38 \mathrm{~dB} \mathrm{SPL}$ 의 청력이 호전되 었고 진행성 난청의 정도도 감소되었다. ${ }^{43)} \operatorname{Crln} 1$ 의 4 번째 엑 손(exon)의 결손을 이용하여 만든 다른 두 종류의 마우스 모 델에서는 각각 아데노연관바이러스 2/8-clrn1과 아데노연관 바이러스 2/9-PHP.B-clrn1를 통해 청력의 호전뿐만 아니라 섬모 다발의 모양도 정상화되었다. ${ }^{44)}$ 특히, 아데노연관바이러 스 2/9-PHP.B를 이용하였을 때는 내유모세포뿐만 아니라 외 
유모세포에서도 바이러스 벡터의 감염 효율이 높았다. 이처럼 같은 질환에서 유전자 치료를 하더라도 사용되는 마우스 모 델 및 바이러스 벡터의 종류에 따라 결과가 다를 수 있다.

Ush1c 유전자는 Usher 증후군 $1 \mathrm{C}$ 의 원인 유전자로 유모 세포 섬모의 골격구조를 이루는 단백질인 harmonin을 코딩 한다. Ush 1c c216G>A 변이는 mRNA의 스플라이싱 부위 (splice site)를 변화시켜 PDZ(postsynaptic density, disc large, zonula occludens)와 PST(proline, serine, threonine) 영역이 결핍되어 있는 비정상 harmonin 단백질을 만든다. 따라서 섬 모가 정상적인 $\mathrm{W}$ 나 $\mathrm{V}$ 자 모양을 형성하지 못한다. ${ }^{45}$ 이 변이 를 갖는 마우스 모델에서 아데노연관바이러스 2/Anc80L65Harmonin $b$ 를 정원창을 통해 내이로 주입했을 때 섬모의 모 양이 정상화되고 청력 및 전정기능도 회복되었다. 그러나 이 성질체(isoform)인 Harmonin $a$ 를 이용하였을 때는 유의한 변화는 없었다. ${ }^{46)}$ 이처럼 유전자 치료를 시행할 때 유전자의 이성질체에 따라 결과가 달라질 수 있다.

\section{시냅스 연결 및 전달: Vglut3, Otof}

Vglut3 단백질은 유모세포에서 신경전달물질인 글루탐산 염(glutamate)을 시냅스 낭포로 전달하는 역할을 한다. 이 단백질이 결핍되어 있는 마우스는 선천적인 난청을 갖는다.47) Vglut3 knock out 마우스에서 아데노연관바이러스 1-Vglut3 를 와우개방술과 정원창 주입을 통해 내이로 전달하였을 때 내유모세포 시냅스에 Vglut3이 발현하였다. 또한 리본 시냅스 (ribbon synapse)의 모양이 회복되고 그로 인해 청력이 회복 되었다. ${ }^{48)}$ 생후 1 3일 사이와 생후 10 12일 사이에 바이러스 벡터를 주입하고 7주 후에 관찰한 청력에서 모든 마우스들이 청력을 회복하였지만 생후 10 12일 사이의 마우스들은 시간 이 지남에 따라 회복되었던 청력이 유의하게 감소하였다. 이 처럼 유전자를 주입하는 치료 시기에 따라 치료 결과가 달라 질 수 있다.

Otof 유전자는 시냅스 낭포의 재형성 및 세포외유출(exocytosis)에 관여하는 otofelin 단백질을 코딩한다. 주로 유모 세포에서 발현을 하며 상염색체 열성 비증후군 난청 6형과 연관이 있다. ${ }^{49)}$ 유전자 코딩 시퀀스(coding sequence)의 크기 가 약 $6 \mathrm{~kb}$ 로 아데노연관바이러스의 운반량의 한도를 넘는 다, 이러한 한계를 극복하기 위해 치료 유전자를 두 개의 아 데노연관바이러스(adeno-associated virus dual vectors) 나 누어 삽입할 수 있다. Otof cDNA의 5' 말단 쪽 절반과 3' 말 단 쪽 절반을 나누어서 Otof knock-out 마우스 모델에 주입 했을 때 약 50\%의 내유모세포에서 otofelin 발현을 확인할 수 있었고 청력이 정상 회복되었다. 25,26$)$ 이처럼 크기가 큰 유 전자도 아데노연관바이러스의 운반 한도 내에서 나누어서 두
개의 아데노연관바이러스를 통해 내이에 전달됨으로써 치료 효과를 얻을 수 있다.

\section{와우내 이온 항상성: Gjb2, Gjb6, SLC26A4}

간극연접(gap junction)을 통해 세포들 사이에 물질들이 이 동한다. 포도당(glucose), adenosine triphosphate 및 mRNA 같은 물질들이 이웃하는 세포들 사이에서 이동한다. Connexin 26과 30은 내이에 존재하는 간극연접으로, Gjb2 유전 자와 GJB6 유전자가 각각 코딩한다. Gjb2 knock-out 마우스 모델에서 아데노연관바이러스 $1-G j b 2$ 를 생후 1 일에 내이로 주입하면 지지세포에서 요오드(propidium iodide) 및 칼세인 (calcein acetoxymethyl ester)의 확산이 관찰된다. 이러한 물질들의 확산은 간극연접의 물질이동 통로로서의 기능회복 을 의미하는 것이다. ${ }^{50)}$ GJB6 knock down 마우스에서 배아 11.5 일에 바이러스 벡터를 주입하면 물질이동의 기능회복뿐 만아니라 청력회복도 관찰할 수 있다. ${ }^{51)}$ 이처럼 $G j b$ 유전자 치료에는 치료시기가 중요하게 작용한다.

$S l c 26 A 4$ 유전자는 내림프액의 항상성 유지에 관여하는 음 이온 교환 통로인 pendrin 단백질을 코딩한다. ${ }^{52,53)}$ Slc26A4 변이는 감각신경성 난청과 갑상선종(goiter)을 특징으로 하는 Pendred 증후군을 일으킨다. Slc26A4 knock out 마우스 모델 을 이용한 연구에서 아데노연관바이러스 2/1-CMV-Slc26a4 를 배아 12.5일 때 이낭(otocyst)에 주입하면 내림프낭(endolymphatic sac)에서의 pendrin의 발현이 증가했다. 또한 청 력도 정상의 10 $20 \mathrm{~dB}$ 이내로 회복되었다. 그러나 이러한 청 력 회복은 지속되지 않았고 전정기능의 회복은 관찰되지 않 았다. ${ }^{54)}$ 이러한 결과들은 pendrin의 발현이 발생 특정시기에 만 발생에 영향을 끼치기 때문일 수 있고, Slc26A4가 와우나 전정기관이 아닌 내림프낭(endolymphatic sac)에서만 발현이 되기 때문일 수 있다.

\section{결 론}

과학의 발전으로 지난 수십 년간 유전자 치료는 많은 발전 을 이루었다. 난청에 여러 유전자들이 관여하고 다양한 기전 에 의해 내이세포들에 영향을 미치므로 종합적이고 정확한 유전학적 진단이 선행되어야 유전자 치료가 효과를 발휘할 수 있다. 여러 마우스 모델들에서 시행된 성공적인 연구들로 비인간 영장류 등으로 그 연구가 확장되고 있다. 안전하고 효 과적인 내이 전달 방법, 목표 세포에 따른 적절한 바이러스 매개체, 향상된 유전자 편집 물질 및 유전자에 따른 최적의 치료 시기 등에 대한 지속적인 연구와 발전이 이루어진다면 실제 유전성 난청 환자들에게 유전자 치료를 적용할 수 있을 
것이다.

\section{Acknowledgments}

The author is grateful for Chungnam National University for supporting the author's research fellowship at inner ear gene therapy program, National Institute on Deafness and other Communication Disorders, National Institutes of Health.

\section{ORCID}

Jin Woong Choi https://orcid.org/0000-0003-3101-6841

\section{REFERENCES}

1) Bowl MR, Simon MM, Ingham NJ, Greenaway S, Santos L, Cater $\mathrm{H}$, et al. A large scale hearing loss screen reveals an extensive unexplored genetic landscape for auditory dysfunction. Nat Commun 2017;8(1):886.

2) World Health Organization. Deafness and hearing loss. [cited 2020 Sep 1] Available from: URL: https://www.who.int/news-room/factsheets/detail/deafness-and-hearing-loss.

3) Smith RJ, Bale JF Jr, White KR. Sensorineural hearing loss in children. Lancet 2005;365(9462):879-90.

4) Kremer H. Hereditary hearing loss; about the known and the unknown. Hear Res 2019;376:58-68.

5) Lentz JJ, Jodelka FM, Hinrich AJ, McCaffrey KE, Farris HE, Spalitta MJ, et al. Rescue of hearing and vestibular function by antisense oligonucleotides in a mouse model of human deafness. Nat Med 2013;19(3):345-50.

6) Shibata SB, Ranum PT, Moteki H, Pan B, Goodwin AT, Goodman $\mathrm{SS}$, et al. RNA interference prevents autosomal-dominant hearing loss. Am J Hum Genet 2016;98(6):1101-13.

7) Kosicki M, Tomberg K, Bradley A. Repair of double-strand breaks induced by CRISPR-Cas9 leads to large deletions and complex rearrangements. Nat Biotechnol 2018;36(8):765-71.

8) Wold WS, Toth K. Adenovirus vectors for gene therapy, vaccination and cancer gene therapy. Curr Gene Ther 2013;13(6):421-33.

9) Sheffield AM, Gubbels SP, Hildebrand MS, Newton SS, Chiorini JA, Di Pasquale G, et al. Viral vector tropism for supporting cells in the developing murine cochlea. Hear Res 2011;277(1-2):28-36.

10) Lee CS, Bishop ES, Zhang R, Yu X, Farina EM, Yan S, et al. Adenovirus-mediated gene delivery: Potential applications for gene and cell-based therapies in the new era of personalized medicine. Genes Dis 2017;4(2):43-63.

11) Shu Y, Tao Y, Wang Z, Tang Y, Li H, Dai P, et al. Identification of adeno-associated viral vectors that target neonatal and adult mammalian inner ear cell subtypes. Hum Gene Ther 2016;27(9): 687-99.

12) Taylor RR, Filia A, Paredes U, Asai Y, Holt JR, Lovett M, et al. Regenerating hair cells in vestibular sensory epithelia from humans. Elife 2018;7:e34817.

13) Bedrosian JC, Gratton MA, Brigande JV, Tang W, Landau J, Bennett J. In vivo delivery of recombinant viruses to the fetal murine cochlea: Transduction characteristics and long-term effects on auditory function. Mol Ther 2006;14(3):328-35.

14) Pan S, Wan J, Liu S, Zhang S, Xiong H, Zhou J, et al. Lentivirus carrying the Atohl gene infects normal rat cochlea. Neural Regen Res 2013;8(17):1551-9.

15) Han JJ, Mhatre AN, Wareing M, Pettis R, Gao WQ, Zufferey RN, et al. Transgene expression in the guinea pig cochlea mediated by a lentivirus-derived gene transfer vector. Hum Gene Ther 1999; 10(11):1867-73.

16) Pietola L, Aarnisalo AA, Joensuu J, Pellinen R, Wahlfors J, Jero J. HOX-GFP and WOX-GFP lentivirus vectors for inner ear gene transfer. Acta Otolaryngol 2008;128(6):613-20.

17) Balakrishnan B, Jayandharan GR. Basic biology of adeno-associated virus (AAV) vectors used in gene therapy. Curr Gene Ther 2014; 14(2):86-100.

18) Geoffroy MC, Salvetti A. Helper functions required for wild type and recombinant adeno-associated virus growth. Curr Gene Ther 2005;5(3):265-71.

19) Naso MF, Tomkowicz B, Perry WL 3rd, Strohl WR. Adenoassociated virus (AAV) as a vector for gene therapy. BioDrugs 2017;31(4):317-34.

20) Grieger JC, Samulski RJ. Adeno-associated virus vectorology, manufacturing, and clinical applications. Methods Enzymol 2012;507:229-54.

21) Wright JF. Manufacturing and characterizing AAV-based vectors for use in clinical studies. Gene Ther 2008;15(11):840-8.

22) Askew C, Rochat C, Pan B, Asai Y, Ahmed H, Child E, et al. Tmc gene therapy restores auditory function in deaf mice. Sci Transl Med 2015;7(295):295ra108.

23) Alexopoulou AN, Couchman JR, Whiteford JR. The CMV early enhancer/chicken beta actin (CAG) promoter can be used to drive transgene expression during the differentiation of murine embryonic stem cells into vascular progenitors. BMC Cell Biol 2008;9:2.

24) Liu Y, Okada T, Nomoto T, Ke X, Kume A, Ozawa K, et al. Promoter effects of adeno-associated viral vector for transgene expression in the cochlea in vivo. Exp Mol Med 2007;39(2):170-5.

25) Akil O, Dyka F, Calvet C, Emptoz A, Lahlou G, Nouaille S, et al. Dual AAV-mediated gene therapy restores hearing in a DFNB9 mouse model. Proc Natl Acad Sci U S A 2019;116(10):4496-501.

26) Al-Moyed H, Cepeda AP, Jung S, Moser T, Kügler S, Reisinger E. A dual-AAV approach restores fast exocytosis and partially rescues auditory function in deaf otoferlin knock-out mice. EMBO Mol Med 2019;11(1):e9396.

27) Kilpatrick LA, Li Q, Yang J, Goddard JC, Fekete DM, Lang H. Adeno-associated virus-mediated gene delivery into the scala media of the normal and deafened adult mouse ear. Gene Ther 2011;18(6): 569-78.

28) Zhu BZ, Saleh J, Isgrig KT, Cunningham LL, Chien WW. Hearing loss after round window surgery in mice is due to middle ear effusion. Audiol Neurootol 2016;21(6):356-64.

29) Yoshimura H, Shibata SB, Ranum PT, Smith RJH. Enhanced viralmediated cochlear gene delivery in adult mice by combining canal fenestration with round window membrane inoculation. Sci Rep 2018;8(1):2980.

30) Tao Y, Huang M, Shu Y, Ruprecht A, Wang H, Tang Y, et al. Delivery of adeno-associated virus vectors in adult mammalian inner-ear cell subtypes without auditory dysfunction. Hum Gene Ther 2018;29(4):492-506.

31) Guo JY, He L, Qu TF, Liu YY, Liu K, Wang GP, et al. Canalostomy as a surgical approach to local drug delivery into the inner ears of adult and neonatal mice. J Vis Exp 2018;(135):57351.

32) Brownstein Z, Friedman LM, Shahin H, Oron-Karni V, Kol N, Abu Rayyan A, et al. Targeted genomic capture and massively parallel sequencing to identify genes for hereditary hearing loss in Middle Eastern families. Genome Biol 2011;12(9):R89.

33) Denoyelle F, Marlin S, Weil D, Moatti L, Chauvin P, Garabédian EN, et al. Clinical features of the prevalent form of childhood deafness, DFNB1, due to a connexin-26 gene defect: Implications for genetic counselling. Lancet 1999;353(9161):1298-303.

34) Yuan Y, You Y, Huang D, Cui J, Wang Y, Wang Q, et al. Comprehensive molecular etiology analysis of nonsyndromic hearing impairment from typical areas in China. J Transl Med 2009;7:79.

35) Ebermann I, Scholl HP, Charbel Issa P, Becirovic E, Lamprecht J, Jurklies B, et al. A novel gene for Usher syndrome type 2: Mutations 
in the long isoform of whirlin are associated with retinitis pigmentosa and sensorineural hearing loss. Hum Genet 2007;121(2):203-11.

36) Mburu P, Mustapha M, Varela A, Weil D, El-Amraoui A, Holme $\mathrm{RH}$, et al. Defects in whirlin, a PDZ domain molecule involved in stereocilia elongation, cause deafness in the whirler mouse and families with DFNB31. Nat Genet 2003;34(4):421-8.

37) Chien WW, Isgrig K, Roy S, Belyantseva IA, Drummond MC, May LA, et al. Gene therapy restores hair cell stereocilia morphology in inner ears of deaf whirler mice. Mol Ther 2016;24(1):17-25.

38) Isgrig K, Shteamer JW, Belyantseva IA, Drummond MC, Fitzgerald TS, Vijayakumar S, et al. Gene therapy restores balance and auditory functions in a mouse model of Usher syndrome. Mol Ther 2017;25(3):780-91.

39) Kawashima Y, Géléoc GS, Kurima K, Labay V, Lelli A, Asai Y, et al. Mechanotransduction in mouse inner ear hair cells requires transmembrane channel-like genes. J Clin Invest 2011;121(12): 4796-809.

40) Marcotti W, Erven A, Johnson SL, Steel KP, Kros CJ. Tmc1 is necessary for normal functional maturation and survival of inner and outer hair cells in the mouse cochlea. J Physiol 2006;574(Pt 3): 677-98.

41) Nist-Lund CA, Pan B, Patterson A, Asai Y, Chen T, Zhou W, et al. Improved $\mathrm{TMCl}$ gene therapy restores hearing and balance in mice with genetic inner ear disorders. Nat Commun 2019;10(1):236.

42) Dulon D, Papal S, Patni P, Cortese M, Vincent PF, Tertrais M, et al. Clarin-1 gene transfer rescues auditory synaptopathy in model of Usher syndrome. J Clin Invest 2018;128(8):3382-401.

43) Geng R, Geller SF, Hayashi T, Ray CA, Reh TA, Bermingham$\mathrm{McDonogh} \mathrm{O}$, et al. Usher syndrome IIIA gene clarin-1 is essential for hair cell function and associated neural activation. Hum Mol Genet 2009;18(15):2748-60.

44) György B, Meijer EJ, Ivanchenko MV, Tenneson K, Emond F, Hanlon KS, et al. Gene transfer with AAV9-PHP.B rescues hearing in a mouse model of Usher syndrome 3A and transduces hair cells in a non-human primate. Mol Ther Methods Clin Dev 2018;13:1-13.

45) Lentz J, Savas S, Ng SS, Athas G, Deininger P, Keats B. The USH1C 216G-->A splice-site mutation results in a 35-base-pair deletion. Hum Genet 2005;116(3):225-7.

46) Pan B, Askew C, Galvin A, Heman-Ackah S, Asai Y, Indzhykulian AA, et al. Gene therapy restores auditory and vestibular function in a mouse model of Usher syndrome type 1c. Nat Biotechnol 2017;35(3):264-72.

47) Yu F, Hao S, Yang B, Zhao Y, Zhang W, Yang J. Mild maternal iron deficiency anemia induces hearing impairment associated with reduction of ribbon synapse density and dysregulation of VGLUT3, myosin VIIa, and prestin expression in young guinea pigs. Neurotox Res 2016;29(4):594-604.

48) Akil O, Seal RP, Burke K, Wang C, Alemi A, During M, et al. Restoration of hearing in the VGLUT3 knockout mouse using virally mediated gene therapy. Neuron 2012;75(2):283-93.

49) Roux I, Safieddine S, Nouvian R, Grati M, Simmler MC, Bahloul A, et al. Otoferlin, defective in a human deafness form, is essential for exocytosis at the auditory ribbon synapse. Cell 2006;127(2): 277-89.

50) Yu Q, Wang Y, Chang Q, Wang J, Gong S, Li H, et al. Virally expressed connexin 26 restores gap junction function in the cochlea of conditional Gjb2 knockout mice. Gene Ther 2014;21(1):71-80.

51) Miwa T, Minoda R, Ise M, Yamada T, Yumoto E. Mouse otocyst transuterine gene transfer restores hearing in mice with connexin 30 deletion-associated hearing loss. Mol Ther 2013;21(6):1142-50.

52) Nakaya K, Harbidge DG, Wangemann P, Schultz BD, Green ED, Wall SM, et al. Lack of pendrin $\mathrm{HCO} 3$ - transport elevates vestibular endolymphatic $[\mathrm{Ca} 2+]$ by inhibition of acid-sensitive TRPV5 and TRPV6 channels. Am J Physiol Renal Physiol 2007;292(5):F131421.

53) Wangemann $P$, Nakaya K, Wu T, Maganti RJ, Itza EM, Sanneman $\mathrm{JD}$, et al. Loss of cochlear HCO3- secretion causes deafness via endolymphatic acidification and inhibition of $\mathrm{Ca} 2+$ reabsorption in a Pendred syndrome mouse model. Am J Physiol Renal Physiol 2007;292(5):F1345-53.

54) Kim MA, Kim SH, Ryu N, Ma JH, Kim YR, Jung J, et al. Gene therapy for hereditary hearing loss by SLC26A4 mutations in mice reveals distinct functional roles of pendrin in normal hearing. Theranostics 2019;9(24):7184-99. 


\section{정답 및 해설}

1. 답 (2)

해설 Branchiootorenal(BOR) 증후군. 상염색체 우성 유전을 보이며, $90 \%$ 의 환자에서 난청을 동반하며, 이에 더불어 전이개 누공, 전이개부속물, 그리고 경부누공 등의 새열기형과 신장의 이상을 동반할 수 있다. 감각신경성, 전음성 혹은 혼합성 난청 등 다양한 난청 종류가 모두 나타날 수 있다. BOR 증후군의 대표적인 원인 유전자는 EYA1 gene으로 투과도(penetrance)는 $100 \%$ 에 달한다.

참고 문헌: 대한이비인후과학회. 이비인후과학:이과. 파주: 군자출판사;2018. p.562-3.

2. 답 (3)

해 설 재발성 다발연골염(relapsing polychondritis). 재발성 다발연골염은 주로 귀, 코, 후두, 기관, 기관지의 연골을 침범하며 발작적이고 진행성 경과를 특징으로 하는 염증성 질환으로서, 일시적, 재발성 염증반응으로 연골구조가 육아조직이나 섬유성 조직으로 대체된다. 그 외에 공막염, 감각신경성 난청, 다발성 관절염, 혈관염, 심장 질환, 피부병변, 사구체 신염 등이 발생하기도 한다. 발병원인은 아직 밝혀져 있지 않으나, 약 $25 \%$ 의 환자에서 류마티스 질환이나 자겨면역 질환이 동 반되는 것으로 보아 면역기능의 장애가 발병에 관여하는 것으로 추측되고 있으며 특히 연골 항원에 대한 자가면역이 중 요한 역할을 하는 것으로 알려져 있다. 귀의 연골염은 약 $95 \%$ 에서 양쪽 귀 모두에서 발생하며 연골부위에 갑작스러운 통증과 압통, 종창이 나타난다. 환자의 약 $49 \%$ 에서는 내이동맥 또는 와우분지의 염증으로 내이증상이 동반될 수 있다. 내이를 침범한 경우 현훈과 난청, 이명과 같은 증상을 보일 수 있다. 비연골 침범은 비페색, 비루, 비출혈, 코의 변형을 초 래하기도 한다. 후두, 기관이 침범되면 초기에는 마른 기침이 있다가 진행하면 애성과 천음이 생기며, 심한 경우에는 기 관내삽관이나 기관절개술이 필요하다. Prednisone은 질병 활성도를 억제하는 데 효과적이며, Prednisone에 반응하지 않으면 methotrexate, cyclophosphamide나 azathioprine과 같은 면역억제제를 사용한다. 참고 문헌: 대한이비인후과학회. 이비인후과학:이과. 파주: 군자출판사;2018. p.168-9. 